OPEN ACCESS

Edited by:

Farhad Taghizadeh-Hesary,

Tokai University, Japan

Reviewed by:

Xiangyun Gao,

China University of

Geosciences, China

John M. Polimeni,

Albany College of Pharmacy and Health Sciences, United States

${ }^{*}$ Correspondence:

Tae Yong Jung

tyjung00@yonsei.ac.kr

Specialty section: This article was submitted to Sustainable Energy Systems and

Policies,

a section of the journa

Frontiers in Energy Research

Received: 17 December 2019

Accepted: 09 April 2020

Published: 05 May 2020

Citation:

Baek YJ, Jung TY and Kang SJ (2020)

Analysis of Residential Lighting Fuel Choice in Kenya: Application of Multinomial Probability Models.

Front. Energy Res. 8:70.

doi: 10.3389/fenrg.2020.00070

\section{Analysis of Residential Lighting Fuel Choice in Kenya: Application of Multinomial Probability Models}

\author{
Yong Jun Baek ${ }^{1}$, Tae Yong Jung ${ }^{2 *}$ and Sung Jin Kang ${ }^{3}$ \\ ${ }^{1}$ Asian Development Bank Institute (ADBI), Tokyo, Japan, ${ }^{2}$ Graduate School of International Studies, Yonsei University, Seoul, \\ South Korea, ${ }^{3}$ Department of Economics, Korea University, Seoul, South Korea
}

Safe, clean, and affordable modern lighting services are crucial for improving the socioeconomic welfare of the underprivileged people in developing countries. However, many of the Kenyan households are deprived of this service, and they continue to use traditional lighting devices to meet their lighting demand. It is essential to understand the determinants which influence the household energy choice to promote the household energy transition from traditional to modern lighting fuels. Therefore, this study examines the determinants of household lighting fuel choice with multinomial probability models using the survey data collected by the Kenya National Bureau of Statistics (KNBS) in 2015/16. The key findings of this study are as follows. First, the results of this study have empirically proven the energy ladder hypothesis as the probability of choosing modern lighting fuel increases with a female household head, and with improvements in income, wealth and education. The energy ladder hypothesis has been confirmed in both cases of the household with and without the choice of grid electricity. Second, different socioeconomic determinants for on- and off-grid household fuel choice are identified, which are the location of household, marital status, and household size. This is an important finding which shows that different policy designs are required to promote energy transition in on- and off-grid households.

Keywords: energy transition, energy ladder hypothesis, household fuel choice, multinomial probability analysis, Kenya

\section{INTRODUCTION}

Modern lighting services are crucial for improving the socio-economic welfare of underprivileged people in developing countries. Those without access to modern lighting services tend to use hazardous and inefficient lighting devices (such as kerosene lamps) to meet their energy demands (Lam et al., 2012). Hence, this paper aims to examine the ways to improve the household energy consumption by promoting energy transition from traditional fuels to modern fuels.

Previous studies examining the household energy transition follow two theoretical approaches, which are the energy ladder hypothesis and energy stacking hypothesis. These two hypotheses have been empirically tested over decades, but similar models have been tested with changes in the independent variables or target country. However, previous studies have not examined the different natures of on- and off-grid households. As the government is responsible for establishing the grid, the grid electricity should not be considered as a choice of a household. Hence, this study challenges the common assumption that the grid electricity is a household choice by hypothesizing 
that the socio-economic determinants which influence the household lighting fuel choice for on- and off-grid household would be different.

A case study on Kenyan households is conducted to examine the various socio-economic determinants, which influences the Kenyan household's lighting fuel choice by using the multinomial probability models. The total household energy demand is a sum of the day-to-day decisions made by households. Thus, it is crucial to have a good understanding of the driving factors which influence a household's lighting fuel choice to promote the energy transition.

Developing countries face a similar challenge from a low electrification rate, and households tend to rely heavily on fossil fuels. Kenya also faces similar difficulties, but it has the potential to overcome the issue and can serve as a role model for other developing countries if well-designed policies are successfully implemented. Moreover, the limited data availability poses a barrier to academic studies in developing countries, but the Kenyan government, with the support of international organizations, has been keeping a good record of the household survey.

The contribution of this study to the existing literature is 2fold. First, the results of this study have empirically proven the energy ladder hypothesis as the probability of choosing modern lighting fuel increases with a female household head, and with improvements in income, wealth and education. This has been confirmed in both cases of the household with and without the choice of grid electricity. Second, different socio-economic determinants for on- and off-grid household fuel choice are identified, which are the location of household, marital status, and household size. This is an important finding which shows that different policy designs are required to promote energy transition in on- and off-grid households. The robustness of the results has been tested with different model specifications. The primary model employed is the multinomial logit model (MNL), but this has the limitation of imposing the independence of irrelevant alternatives (IIA) assumption. Thus, the multinomial probit model (MNP) and the alternative-specific MNP are used to check that the IIA assumption is not violated.

The rest of this study is structured as follows. section Literature Review presents the previous studies, and then section Methodology presents the data and model specification. Afterward, section Results and Analysis discusses the results with the robustness check, and section Conclusion and Policy Recommendations concludes with policy suggestions for Kenya and other developing countries.

\section{LITERATURE REVIEW}

The critical conceptual framework of this study is the household energy transition, which is dealt with by two key hypotheses: the energy ladder hypothesis; and the energy stacking hypothesis. The energy ladder hypothesis assumes that as the income rises, the household would make a transition (stepping up the energy ladder) from traditional fuels to modern fuels (Leach, 1992; van der Kroon et al., 2013). At the household level, empirical studies have repeatedly confirmed that income is a crucial component of fuel choice (Farsi et al., 2007; Hiemstra-Van der Horst and
Hovorka, 2008; Danlami et al., 2017). Thus, socio-economic determinants other than income need to be examined to test the energy ladder hypothesis empirically.

On the other hand, the energy ladder hypothesis has been criticized as energy transition is not a step by step process, but rather an overlapping process with multiple fuels being used simultaneously. This is known as fuel stacking, and the energy stacking hypothesis assumes that the households would adopt modern fuels as the income rises, but also continue to use traditional fuels as well. Several empirical studies have tested and confirmed the fuel stacking behaviors in developing countries (Masera et al., 2000; Heltberg, 2004, 2005; Mekonnen and Köhlin, 2009; Andadari et al., 2014; Cheng and Urpelainen, 2014; RuizMercado and Masera, 2015; Alem et al., 2016).

Given the importance of household energy consumption, a large pool of literature exists for household cooking fuel choice, but only a handful of researches have been conducted on household lighting fuel choice (Lay et al., 2013; Olang et al., 2018; Choumert-Nkolo et al., 2019). Also, Giri and Goswami (2017) report household location, gender, education level, family size, size of dependent families, and market distance as the significant determinants for the household choice of electricity as the main lighting fuel. Danlami et al. (2017) present income, age of the household head, urban location, number of rooms, and access to electricity to have a positive influence on the adoption of electricity as the main lighting fuel. Rahut et al. (2017) examine the determinants of the household's electricity use in four African countries (Ethiopia, Malawi, Tanzania, and Uganda). The results show that female-headed households, education level, household location, wealth, and access to infrastructure are common determinants that influence the household's use of electricity as the main lighting fuel. Martey (2019) examines the Ghanaian household's lighting and cooking fuel choice using the linear probability model and the bivariate probit model. The estimated result identified several components influencing household fuel choices, such as basic demographics (age and education), poverty, household expenditure, saving, remittances, and housing characteristics.

This study contributes to the existing literature in two ways. First, the energy ladder hypothesis is empirically tested. The previous studies have shown that multinomial probability models using cross-sectional dataset is unsuitable for examining the fuel stacking behavior, which requires a panel data ${ }^{1}$. However, the energy ladder hypothesis and the determinants of household lighting fuel choice can still be examined using the cross-sectional dataset. Therefore, this study will examine whether income and other socio-economic determinants show the behaviors discussed in the energy ladder hypothesis.

Second, the socio-economic determinants for the off-grid household fuel choice are identified. The previous studies have assumed that grid electricity is a choice of equal value to other alternative lighting fuel choices. This study challenges this

\footnotetext{
${ }^{1}$ Kenyan households do use secondary lighting fuels in case they cannot use the main lighting fuel, but no meaningful analysis can be conducted without seeing a change in the fuel stacks. Other studies examining the fuel stacking behavior analyzes the difference between before and after of household fuel stacks [e.g. (Andadari et al., 2014)].
} 
assumption by arguing that the households have no control over grid electricity; thus, it should not be treated as a choice like other alternative fuels. The government needs to build the necessary infrastructure and supply adequate electricity for the household to benefit from this service. In other words, the off-grid households should not have the choice of grid electricity. Therefore, a new sample (excluding the households with grid connection) is used to examine the determinants of the household lighting choice.

\section{METHODOLOGY}

\section{Theoretical Framework}

MNL is a frequently used regression technique for assessing discrete choice data, such as the household lighting fuel choice. van der Kroon et al. (2013) provide a list of studies that have used MNL to examine the energy transition and fuel switching behavior. In this study, MNL is used to analyze the Kenya Integrated Household Budget Survey (KIHBS) 2015/16. The dependent variable includes four distinct unordered alternatives (grid electricity, solar panel, kerosene and battery torch) used for lighting purposes ${ }^{2}$. The basic equation for the MNL is as follows:

$$
\operatorname{Prob}\left(Y_{i}=j\right)=\frac{\exp \left(\beta_{j} x_{i}\right)}{\sum_{k=1}^{j} \exp \left(\beta_{k} x_{i}\right)} \text { with } j=1,2,3,4
$$

Where $Y_{i}$ is the household's lighting fuel choice and takes the value of 1 to 4 if alternative fuels are chosen instead of the reference fuel. $x_{i}$ is the vector of independent variables that affect the household fuel choice. $\beta_{j}$ is the vector of estimated coefficients. Afterward, the outcome is shown in odds ratios, which are the ratios of the probability of choosing an alternative fuel over the reference fuel. The equation for the odds ratios is as follows:

$$
l_{n}\left[\frac{P_{i j}}{P_{i k}}\right]=X_{i}\left(\beta_{j}-\beta_{k}\right)=X_{i} \beta_{j} \text { if } k=1
$$

A positive ratio means that the probability of a household choosing an alternative fuel than the reference fuel increases relative to the probability of a household choosing the reference fuel than the alternative fuel, and vice versa. The reference fuel could be any fuel type, but in this study, kerosene is the reference fuel as it is the most commonly used lighting fuel.

\section{Data and Descriptive Statistics}

This study uses a cross-sectional survey data collected by the Kenya National Bureau of Statistics (KNBS) in 2015/16 across Kenya. This data is processed to select the household's main lighting fuels and the key determinants which influence the household's lighting fuel choice, as discussed in section Literature Review. The dependent variable is a set of lighting fuels which are available to the Kenyan households. The independent variables are chosen based on previous studies and data availability.

\footnotetext{
${ }^{2}$ This is the full list of available household lighting fuel choices, but the choices vary for different estimation models.
}

\begin{tabular}{|c|c|c|c|c|}
\hline \multirow[t]{2}{*}{ Variables } & \multicolumn{2}{|c|}{ Full sample } & \multicolumn{2}{|c|}{ No grid sample } \\
\hline & Observation & Mean & Observation & Mean \\
\hline Lighting fuels & \multicolumn{2}{|c|}{20,605} & \multicolumn{2}{|c|}{13,190} \\
\hline - Grid electricity & 6,881 & 33.39 & $\mathrm{n} / \mathrm{a}$ & $\mathrm{n} / \mathrm{a}$ \\
\hline - Solar panel & 3,501 & 16.99 & 3,038 & 23.03 \\
\hline - Kerosene & 8,247 & 40.02 & 8,187 & 62.07 \\
\hline - Battery torch & 1,976 & 9.59 & 1,965 & 14.90 \\
\hline Age [scaled by 100] & 21,161 & 44.54 & 14,287 & 46.40 \\
\hline Income & 18,870 & $11,310.41$ & 12,629 & 6820.40 \\
\hline Rooms & 21,145 & 2.21 & 14,269 & 2.16 \\
\hline Household size & 21,187 & 4.25 & 14,306 & 4.63 \\
\hline Dwelling type dummy & \multicolumn{2}{|c|}{21,195} & \multicolumn{2}{|c|}{14,314} \\
\hline - Modern & 18,331 & 86.49 & 11,553 & 80.71 \\
\hline - Traditional & 2,864 & 13.51 & 2,761 & 19.29 \\
\hline Location dummy & \multicolumn{2}{|c|}{21,195} & \multicolumn{2}{|c|}{14,314} \\
\hline - Urban & 8,637 & 40.75 & 3,559 & 24.86 \\
\hline - Rural & 12,558 & 59.25 & 10,755 & 75.14 \\
\hline Marital status dummy & \multicolumn{2}{|c|}{21,195} & \multicolumn{2}{|c|}{14,314} \\
\hline - Married & 6,221 & 29.35 & 4,185 & 29.24 \\
\hline - Not married & 14,974 & 70.65 & 10,129 & 70.76 \\
\hline Gender dummy & \multicolumn{2}{|c|}{21,195} & \multicolumn{2}{|c|}{14,314} \\
\hline - Male & 14,088 & 66.47 & 9,229 & 64.48 \\
\hline - Female & 7,107 & 33.53 & 5,085 & 35.52 \\
\hline Education dummy & \multicolumn{2}{|c|}{21,195} & \multicolumn{2}{|c|}{14,314} \\
\hline - No education & 4,067 & 19.19 & 3,633 & 25.39 \\
\hline - Primary school & 9,279 & 43.78 & 7,230 & 50.51 \\
\hline - Secondary school & 5,151 & 24.30 & 2,706 & 18.90 \\
\hline - Tertiary school & 2,698 & 12.73 & 745 & 5.20 \\
\hline Kerosene price & 20,767 & 93.23 & 13,940 & 96.60 \\
\hline Electrification rate & 21,195 & 32.43 & $\mathrm{n} / \mathrm{a}$ & $\mathrm{n} / \mathrm{a}$ \\
\hline
\end{tabular}

TABLE 1 | Descriptive statistics.

The unit of mean is in percentage, except for age, income, rooms, household size, and kerosene price variables.

The descriptive statistics of the selected variables are presented in Table 1.

As this study examines two different samples (a full sample and a sample excluding households with grid connection), separate descriptive statistics are presented for each sample. The lighting fuels are organized into a categorical variable representing the household's fuel choice. The age variable represents the age of the household head, which is scaled by 100. Income variable represents the household's monthly income, which is transformed using the natural log. The rooms variable represents the number of rooms available for the household, while the household size variable represents the number of people in the household. The dwelling type dummy represents the housing style with a modern style as 1 .

The location dummy represents the location of the household with urban as 1 . The marital status dummy represents the marital status of the household head with married being 1 and the gender dummy represents the gender of the household head with a female as 1 . The education dummy represents the final level of 
TABLE 2 | Household's monthly lighting fuel expenditure in Kenyan shillings (KSh).

\begin{tabular}{lcccr}
\hline Lighting fuel & Observation & Mean & S.D. & Median \\
\hline Grid electricity & 4,822 & 579.67 & 843.23 & 380.00 \\
Kerosene & 9,821 & 170.76 & 183.08 & 120.00 \\
Dry cell battery & 2,124 & 117.47 & 151.08 & 80.00 \\
Lead cell battery & 181 & 125.14 & 387.63 & 50.00 \\
\hline
\end{tabular}

Source: KIHBS 2015/16.

education received by the household head with no education as the reference. The kerosene price variable is the price paid by each household to purchase a liter of kerosene, and the average kerosene price of each county is used for the households without a survey response. Lastly, the electrification rate is the proportion of electrified (grid-connected) households in each cluster. The correlation matrix of the independent variables is provided in Table A1.

Kerosene is the most commonly used lighting fuel as it is reliable and relatively cheap, with the average price of 84.04 KSh/liter (about $0.83 \mathrm{USD} /$ liter $^{3}$ ) in 2014 . Table 2 presents the average monthly expenditure of kerosene, which is $170.76 \mathrm{KSh}$ (about 1.69 USD). Grid electricity is the second most used lighting fuel but has a high average price of $691 \mathrm{KSh}$ (about 6.84 USD) for $50 \mathrm{kWh}$ in 2014 . The average monthly expenditure is 579.67 KSh (about 5.73 USD).

Harper et al. (2013) present the price of off-grid lighting devices in three Kenyan towns of Kericho, Brooke, and Talek. Many different types of battery torches exist, but for most of the products, the prices were usually below 300 KSh (about 2.97 USD) in 2012. A caveat is that this is the price of the device only, and the average monthly expenditure of batteries is in the range of 117.47-125.14 KSh (about 1.16-1.24 USD).

The advantage of solar panel products is that there is no monthly expenditure, but it has a high upfront cost. Furthermore, the quality of solar panel products is not guaranteed in Kenya, so the household may have to pay an additional maintenance fee (Harper et al., 2013).

\section{RESULTS AND ANALYSIS}

\section{Estimation Results}

Initially, the full sample (including households with grid connection) is estimated to examine whether the results are similar to previous studies. The estimated coefficients for alternative lighting fuels are compared with kerosene, which is the reference fuel in this model. Table 3 presents the anticipated results. If a household has a grid connection, grid electricity will be the most preferred lighting fuel choice. The estimated coefficients of most of the variables show positive and statistically significant results for grid electricity. On the contrary, the estimated coefficients of most of the variables tend to show

\footnotetext{
${ }^{3}$ Exchange rate of 1 USD to 101.1 KSh (15 May 2019) is used in this study. The conversion is to compare the price of the goods in terms of USD, and serves no other purpose.
}

TABLE 3 | Average marginal effects of household lighting fuel choice (Full sample).

\begin{tabular}{|c|c|c|c|c|}
\hline & $\begin{array}{c}\text { Grid } \\
\text { electricity }\end{array}$ & Solar panel & Kerosene & Battery torch \\
\hline Age & $\begin{array}{c}-1.054^{\star \star \star} \\
(0.17)\end{array}$ & $\begin{array}{c}-0.00378 \\
(0.15)\end{array}$ & $\begin{array}{c}1.055^{\star \star \star} \\
(0.19)\end{array}$ & $\begin{array}{r}0.00324 \\
(0.044)\end{array}$ \\
\hline $\mathrm{Age}^{2}$ & $\begin{array}{c}1.052^{\star \star \star} \\
(0.18)\end{array}$ & $\begin{array}{c}-0.00625 \\
(0.15)\end{array}$ & $\begin{array}{c}-1.007^{\star \star \star} \\
(0.19)\end{array}$ & $\begin{array}{c}-0.0386 \\
(0.044)\end{array}$ \\
\hline $\begin{array}{l}\text { Location } \\
(\text { Urban =1) }\end{array}$ & $\begin{array}{c}0.0247^{\star \star} \\
(0.01)\end{array}$ & $\begin{array}{c}-0.0265^{\star \star \star} \\
(0.01)\end{array}$ & $\begin{array}{r}0.0103 \\
(0.01)\end{array}$ & $\begin{array}{c}-0.00856^{\star \star \star} \\
(0.003)\end{array}$ \\
\hline $\begin{array}{l}\text { Gender } \\
(\text { Female = 1) }\end{array}$ & $\begin{array}{c}0.0323^{\star \star \star} \\
(0.01)\end{array}$ & $\begin{array}{c}-0.00316 \\
(0.01)\end{array}$ & $\begin{array}{c}-0.0126 \\
(0.01)\end{array}$ & $\begin{array}{c}-0.0166^{\star \star \star} \\
(0.003)\end{array}$ \\
\hline $\begin{array}{l}\text { Marital status } \\
(\text { Married =1) }\end{array}$ & $\begin{array}{c}-0.0771^{\star \star \star} \\
(0.01)\end{array}$ & $\begin{array}{c}-0.0393^{\star \star \star} \\
(0.01)\end{array}$ & $\begin{array}{c}0.114^{\star \star \star} \\
(0.01)\end{array}$ & $\begin{array}{r}0.00267 \\
(0.003)\end{array}$ \\
\hline Household size & $\begin{array}{c}-0.0149^{\star \star \star} \\
(0.002)\end{array}$ & $\begin{array}{c}0.00917^{\star \star \star} \\
(0.001)\end{array}$ & $\begin{array}{c}0.00475^{\star \star} \\
(0.002)\end{array}$ & $\begin{array}{c}0.000955^{\star} \\
(0.001)\end{array}$ \\
\hline Primary education & $\begin{array}{c}0.0245 \\
(0.02)\end{array}$ & $\begin{array}{c}0.0487^{\star \star \star} \\
(0.01)\end{array}$ & $\begin{array}{c}-0.0288^{*} \\
(0.02)\end{array}$ & $\begin{array}{c}-0.0443^{\star \star \star} \\
(0.004)\end{array}$ \\
\hline Secondary education & $\begin{array}{c}0.128^{\star \star \star} \\
(0.02)\end{array}$ & $\begin{array}{c}0.0844^{\star \star \star} \\
(0.02)\end{array}$ & $\begin{array}{c}-0.171^{\star \star \star} \\
(0.02)\end{array}$ & $\begin{array}{c}-0.0419^{\star \star \star} \\
(0.003)\end{array}$ \\
\hline Tertiary education & $\begin{array}{c}0.366^{\star \star \star} \\
(0.03)\end{array}$ & $\begin{array}{c}0.0388^{\star} \\
(0.02)\end{array}$ & $\begin{array}{c}-0.376^{\star \star \star} \\
(0.02)\end{array}$ & $\begin{array}{c}-0.0290^{\star \star \star} \\
(0.003)\end{array}$ \\
\hline $\begin{array}{l}\text { Dwelling type } \\
\text { (Modern }=1 \text { ) }\end{array}$ & $\begin{array}{c}0.149^{\star \star \star} \\
(0.02)\end{array}$ & $\begin{array}{c}0.0335^{\star \star \star} \\
(0.01)\end{array}$ & $\begin{array}{c}-0.124^{\star \star \star} \\
(0.02)\end{array}$ & $\begin{array}{c}-0.0587^{\star \star \star} \\
(0.007)\end{array}$ \\
\hline Rooms & $\begin{array}{c}0.0627^{\star \star \star} \\
(0.004)\end{array}$ & $\begin{array}{c}0.0305^{\star \star \star} \\
(0.003)\end{array}$ & $\begin{array}{c}-0.0695^{\star \star \star} \\
(0.005)\end{array}$ & $\begin{array}{c}-0.0237^{\star \star \star} \\
(0.002)\end{array}$ \\
\hline In(income) & $\begin{array}{c}0.0152^{\star \star \star} \\
(0.002)\end{array}$ & $\begin{array}{c}0.00129 \\
(0.001)\end{array}$ & $\begin{array}{c}-0.0163^{\star \star \star} \\
(0.002)\end{array}$ & $\begin{array}{c}-0.000191 \\
(0.0003)\end{array}$ \\
\hline In(kerosene price) & $\begin{array}{c}0.251^{\star \star \star} \\
(0.01)\end{array}$ & $\begin{array}{c}0.181^{\star \star \star} \\
(0.01)\end{array}$ & $\begin{array}{c}-0.475^{\star \star \star} \\
(0.02)\end{array}$ & $\begin{array}{c}0.0432^{\star \star \star} \\
(0.004)\end{array}$ \\
\hline In(electrification rate) & $\begin{array}{c}1.571^{\star \star *} \\
(0.03)\end{array}$ & $\begin{array}{c}-0.592^{\star \star \star} \\
(0.02)\end{array}$ & $\begin{array}{c}-0.888^{\star \star \star} \\
(0.03)\end{array}$ & $\begin{array}{c}-0.0913^{\star \star \star} \\
(0.008)\end{array}$ \\
\hline Observations & & 18,840 & & \\
\hline Pseudo $R^{2}$ & & 0.4067 & & \\
\hline Log-likelihood & & $-13,211.69$ & & \\
\hline
\end{tabular}

No education is the reference for education dummies, Standard errors in parentheses, ${ }^{* * *} p<0.01,{ }^{* *} p<0.05,{ }^{*} p<0.1$.

negative and statistically significant results for other alternative fuel types.

The result empirically confirms the energy ladder hypothesis; when income rises, the probability of a household choosing grid electricity as the main lighting fuel also increases. The estimated coefficient of income shows that a one-unit increase in the monthly income of the household would increase the probability of choosing grid electricity by $1.5 \%$. Other variables (dwelling type and the number of rooms) that indicate the wealth of the household also support the energy ladder hypothesis. The estimated coefficients of dwelling type and the number of rooms are positive and statistically significant for grid electricity. On the contrary, when a household lives in a modern style house, the probability of choosing kerosene and battery are reduced by 12.4 and $5.9 \%$, respectively, compared to a household living in a traditional style house. Similarly, the results show that a one-unit increase in the number of rooms would reduce the probability of choosing kerosene and battery by 7.0 and $2.4 \%$, respectively. 
Another important variable regarding the energy ladder hypothesis is education. Different educational levels are reflected as dummies in the model to examine the effect of education in detail. As expected, the estimated coefficients are positive and statistically significant for grid electricity. When the household head has received secondary and tertiary education, the probability of choosing grid electricity is increased by 12.8 and $36.6 \%$, respectively, compared to other educational levels. It is interesting to note that as the household head receives higher education, the probability of choosing modern fuel type is increased by the interval of around $20 \%$. This result shows the importance of education in designing policies regarding household energy transition.

The estimated coefficient of a household with a female household head is positive and statistically significant at a $5 \%$ confidence level. The result indicates that when the household head is female, the probability of a choosing grid electricity is increased by $3.2 \%$ than the male counterpart. Furthermore, a one-unit increase in the electrification rate of the cluster increases the probability of choosing grid electricity as the main lighting fuel by $157 \%$, which shows the importance of grid accessibility.

The determinants of household lighting fuel choice identified above are similar to the results of Lay et al. $(2013)^{4}$. Therefore, the first model is well-designed with relevant independent variables. However, the main question of this study is to examine whether the determinants of household lighting fuel choice is the same for both the households with and without grid connections.

Previous studies have assumed that grid electricity is a choice of equal value to other alternative lighting fuel choices. This study challenges this assumption by arguing that the households have no control over grid electricity; thus, it should not be treated as a choice like other alternative fuels. The government needs to build the necessary infrastructure and supply adequate electricity for the household to benefit from this service. In other words, the off-grid households should not have the choice of grid electricity. Therefore, a new sample (excluding the households with grid connection) is used to examine the determinants of the household lighting choice.

The expected result was that all variables would be positive and statistically significant for solar panels, which is the next modern energy to grid electricity. However, the result is quite interesting as the determinants for lighting fuel choice are divided between the solar panel and kerosene (see Table 4).

The energy ladder hypothesis is once again empirically confirmed as the probability of the household choosing the solar panel as the main lighting fuel increases when the income rises. The estimated coefficient of income shows that a one-unit increase in the monthly income would increase the probability of choosing a solar panel by $0.7 \%$ while decreasing the probability of choosing kerosene by $0.7 \%$.

Afterward, the proxy variables for the wealth of the household also support the energy ladder hypothesis. The estimated coefficients of the dwelling type and the number of rooms are positive and statistically significant for the solar panel. The

${ }^{4}$ The authors used the survey data of KIHBS 2005/06 to examine the determinants of household lighting fuel choice.
TABLE 4 | Average marginal effects of household lighting fuel choice (No grid sample).

\begin{tabular}{|c|c|c|c|}
\hline & Solar Panel & Kerosene & Battery torch \\
\hline Age & $\begin{array}{c}-0.360^{\star \star} \\
(0.179)\end{array}$ & $\begin{array}{c}0.428^{\star \star} \\
(0.186)\end{array}$ & $\begin{array}{r}-0.069 \\
(0.072)\end{array}$ \\
\hline $\mathrm{Age}^{2}$ & $\begin{array}{c}0.360^{\star \star} \\
(0.179)\end{array}$ & $\begin{array}{r}-0.364^{*} \\
(0.186)\end{array}$ & $\begin{array}{l}0.0036 \\
(0.073)\end{array}$ \\
\hline $\begin{array}{l}\text { Location } \\
\text { (Urban =1) }\end{array}$ & $\begin{array}{c}-0.0449^{\star \star \star} \\
(0.0097)\end{array}$ & $\begin{array}{c}0.064^{\star \star \star} \\
(0.01)\end{array}$ & $\begin{array}{c}-0.019^{\star \star \star} \\
(0.004)\end{array}$ \\
\hline $\begin{array}{l}\text { Gender } \\
(\text { Female = 1) }\end{array}$ & $\begin{array}{c}0.0181^{*} \\
(0.011)\end{array}$ & $\begin{array}{l}0.0098 \\
(0.011)\end{array}$ & $\begin{array}{c}-0.0278^{\star \star \star} \\
(0.0042)\end{array}$ \\
\hline $\begin{array}{l}\text { Marital status } \\
(\text { Married }=1)\end{array}$ & $\begin{array}{c}-0.0789^{\star \star \star} \\
(0.011)\end{array}$ & $\begin{array}{c}0.079^{\star \star \star} \\
(0.012)\end{array}$ & $\begin{array}{c}-0.0005 \\
(0.005)\end{array}$ \\
\hline Household size & $\begin{array}{c}0.011^{\star * *} \\
(0.002)\end{array}$ & $\begin{array}{c}-0.0118^{\star \star \star} \\
(0.002)\end{array}$ & $\begin{array}{l}0.0007 \\
(0.001)\end{array}$ \\
\hline Primary education & $\begin{array}{c}0.0636^{\star \star \star} \\
(0.014)\end{array}$ & $\begin{array}{l}0.0196 \\
(0.015)\end{array}$ & $\begin{array}{c}-0.0832^{\star \star \star} \\
(0.006)\end{array}$ \\
\hline Secondary education & $\begin{array}{c}0.146^{\star \star \star} \\
(0.019)\end{array}$ & $\begin{array}{c}-0.085^{\star \star \star} \\
(0.02)\end{array}$ & $\begin{array}{c}-0.062^{\star \star \star} \\
(0.004)\end{array}$ \\
\hline Tertiary education & $\begin{array}{c}0.257^{\star \star \star} \\
(0.029)\end{array}$ & $\begin{array}{c}-0.222^{\star \star \star} \\
(0.029)\end{array}$ & $\begin{array}{c}-0.035^{\star \star \star} \\
(0.004)\end{array}$ \\
\hline $\begin{array}{l}\text { Dwelling type } \\
\text { (Modern = 1) }\end{array}$ & $\begin{array}{c}0.067^{\star \star \star} \\
(0.013)\end{array}$ & $\begin{array}{l}0.0093 \\
(0.015)\end{array}$ & $\begin{array}{c}-0.077^{\star \star \star} \\
(0.009)\end{array}$ \\
\hline Rooms & $\begin{array}{c}0.0515^{\star \star \star} \\
(0.004)\end{array}$ & $\begin{array}{c}-0.016^{\star \star \star} \\
(0.0045)\end{array}$ & $\begin{array}{c}-0.036^{\star \star \star} \\
(0.002)\end{array}$ \\
\hline In(income) & $\begin{array}{c}0.0069^{\star \star \star} \\
(0.0013)\end{array}$ & $\begin{array}{c}-0.007^{\star \star \star} \\
(0.0015)\end{array}$ & $\begin{array}{c}0.001 \\
(0.0005)\end{array}$ \\
\hline In(kerosene price) & $\begin{array}{c}0.260^{\star \star \star} \\
(0.013)\end{array}$ & $\begin{array}{c}-0.342^{\star \star \star} \\
(0.015)\end{array}$ & $\begin{array}{c}0.0821^{\star \star \star} \\
(0.0051)\end{array}$ \\
\hline Observations & & 11,489 & \\
\hline Pseudo $R^{2}$ & & 0.1915 & \\
\hline Log-likelihood & & $-8,112.65$ & \\
\hline
\end{tabular}

No education is the reference for education dummies, Standard errors in parentheses, ${ }^{* \star *} p<0.01,{ }^{* \star} p<0.05,{ }^{*} p<0.1$.

modern style house increases the probability of choosing a solar panel by $6.7 \%$ compared to the traditional style house. The number of rooms is related to the wealth of a household as more rooms often mean a larger house. A one-unit increase in the number of rooms would increase the probability of choosing a solar panel by $5.2 \%$ but decreases the probability of choosing kerosene by $1.6 \%$.

The estimated coefficients of education variables are positive and statistically significant for the solar panel. When the household head has received primary, secondary, and tertiary education, the probability of choosing solar panel is increased by $6.3,14.6$, and $25.7 \%$, respectively, compared to other educational levels. Therefore, once again, the education variables support the energy ladder hypothesis.

The result gets interesting as location and marital status are positive and statistically significant for kerosene, but negative and statistically significant for solar panel. The result shows that for a household living in an off-grid urban area, the probability of choosing kerosene would increase by $6.4 \%$ compared to a household living in an off-grid rural area. 
The reason for this is because the price and accessibility of kerosene serve as a barrier for households in the rural areas. For example, the distance to the urban center from the rural villages are about $8 \mathrm{~km}$ for Kisumu city, and in the range of $16-46 \mathrm{~km}$ for Meru city. Also, the median price per liter of kerosene was $46 \%$ higher in rural villages than in the urban center in 2011 (Tracy and Jacobson, 2012). On top of this, the households living in urban areas tend to have a higher demand for kerosene as it is used for both lighting and cooking (Ngeno et al., 2018). Therefore, kerosene is a cheap source of lighting for the urban households, but relatively expensive for the rural households. Furthermore, there is no incentive for urban households to use expensive solar panels when a cheaper alternative exists.

When the household head is married, the probability of choosing kerosene as the main lighting fuel increases by $7.9 \%$ compared to the single household heads. Married couples tend to have higher monthly expenditure than a single household, and the high upfront cost of solar panels may be unbearable for some households. In addition, a solar panel provides the most benefit when there is a high demand for electricity, but this is not the case for most of the Kenyan households. Therefore a one-unit increase

TABLE 5 | Average marginal effects of the multinomial probit model.

\begin{tabular}{|c|c|c|c|}
\hline & Solar panel & Kerosene & Battery torch \\
\hline Age & $\begin{array}{c}-0.363^{\star \star} \\
(0.175)\end{array}$ & $\begin{array}{l}0.449^{* *} \\
(0.184)\end{array}$ & $\begin{array}{r}-0.087 \\
(0.088)\end{array}$ \\
\hline $\mathrm{Age}^{2}$ & $\begin{array}{c}0.374^{\star *} \\
(0.175)\end{array}$ & $\begin{array}{c}-0.375^{\star \star} \\
(0.184)\end{array}$ & $\begin{array}{l}0.001 \\
(0.089)\end{array}$ \\
\hline $\begin{array}{l}\text { Location } \\
(\text { Urban }=1)\end{array}$ & $\begin{array}{c}-0.049^{\star \star \star} \\
(0.01)\end{array}$ & $\begin{array}{c}0.071^{\star \star *} \\
(0.01)\end{array}$ & $\begin{array}{c}-0.022^{\star \star \star} \\
(0.005)\end{array}$ \\
\hline $\begin{array}{l}\text { Gender } \\
(\text { Female =1) }\end{array}$ & $\begin{array}{l}0.018^{*} \\
(0.011)\end{array}$ & $\begin{array}{l}0.017 \\
(0.011)\end{array}$ & $\begin{array}{c}-0.036^{\star \star \star} \\
(0.005)\end{array}$ \\
\hline $\begin{array}{l}\text { Marital status } \\
(\text { Married =1) }\end{array}$ & $\begin{array}{c}-0.076^{\star \star \star} \\
(0.011)\end{array}$ & $\begin{array}{c}0.077^{\star \star *} \\
(0.012)\end{array}$ & $\begin{array}{c}-0.0014 \\
(0.006)\end{array}$ \\
\hline Household size & $\begin{array}{c}0.012^{\star \star \star} \\
(0.002)\end{array}$ & $\begin{array}{c}-0.012^{\star \star \star} \\
(0.002)\end{array}$ & $\begin{array}{l}0.0004 \\
(0.001)\end{array}$ \\
\hline Primary education & $\begin{array}{l}0.061^{\star \star \star} \\
(0.0131)\end{array}$ & $\begin{array}{c}0.044^{\star \star \star} \\
(0.014)\end{array}$ & $\begin{array}{c}-0.105^{\star \star \star} \\
(0.007)\end{array}$ \\
\hline Secondary education & $\begin{array}{c}0.135^{\star \star \star} \\
(0.018)\end{array}$ & $\begin{array}{c}-0.058^{\star * \star} \\
(0.018)\end{array}$ & $\begin{array}{c}-0.0767^{\star \star \star} \\
(0.004)\end{array}$ \\
\hline Tertiary education & $\begin{array}{c}0.246^{\star \star \star} \\
(0.026)\end{array}$ & $\begin{array}{c}-0.199^{\star \star \star} \\
(0.026)\end{array}$ & $\begin{array}{c}-0.0478^{\star \star \star} \\
(0.004)\end{array}$ \\
\hline $\begin{array}{l}\text { Dwelling type } \\
(\text { Modern = 1) }\end{array}$ & $\begin{array}{c}0.066^{\star \star \star} \\
(0.013)\end{array}$ & $\begin{array}{c}0.044^{\star \star \star} \\
(0.015)\end{array}$ & $\begin{array}{c}-0.11^{\star \star \star} \\
(0.011)\end{array}$ \\
\hline Rooms & $\begin{array}{c}0.053^{\star \star \star} \\
(0.004)\end{array}$ & $\begin{array}{c}-0.015^{\star \star \star} \\
(0.005)\end{array}$ & $\begin{array}{c}-0.0384^{\star \star \star} \\
(0.003)\end{array}$ \\
\hline In(income) & $\begin{array}{c}0.006^{\star \star \star} \\
(0.001)\end{array}$ & $\begin{array}{c}-0.007^{\star \star \star} \\
(0.001)\end{array}$ & $\begin{array}{c}0.001 \\
(0.0017)\end{array}$ \\
\hline In(kerosene price) & $\begin{array}{c}0.205^{\star \star \star} \\
(0.011)\end{array}$ & $\begin{array}{c}-0.291^{\star \star \star} \\
(0.011)\end{array}$ & $\begin{array}{c}0.0856^{\star \star \star} \\
(0.005)\end{array}$ \\
\hline Observations & & 11,489 & \\
\hline Wald chi2 & & $2,889.54$ & \\
\hline Prob>chi2 & & 0.0000 & \\
\hline Log-likelihood & & $-8,172.05$ & \\
\hline
\end{tabular}

No education is the reference for education dummies, Standard errors in parentheses, ${ }^{\star \star *} p<0.01,{ }^{* \star} p<0.05,{ }^{*} p<0.1$. in the household size would increase the probability of choosing a solar panel by $1.1 \%$, while decreasing the probability of choosing kerosene by $1.2 \%$.

The results have empirically proven the energy ladder hypothesis as the probability of choosing modern lighting fuel increases with a female household head, and with improvements in income, wealth and education. This has been confirmed in both cases of the household with and without the choice of grid electricity. However, some socio-economic determinants show varied results, which are location of household, marital status, and household size. This is an important finding which shows that the households in the off-grid setting would require different policy designs to promote the energy transition from traditional to modern energy types and to improve the household energy consumption.

\section{Robustness Tests}

The results in the previous subsection would be biased and inconsistent if the errors are found in the model assumptions. The MNL assumes the IIA assumptions, meaning that no

TABLE 6 | Average marginal effects of the alternative-specific multinomial probit model.

\begin{tabular}{|c|c|c|c|}
\hline & Solar panel & Kerosene & Battery torch \\
\hline Age & $\begin{array}{r}-0.374^{\star} \\
(0.192)\end{array}$ & $\begin{array}{c}0.463^{\star \star} \\
(0.199)\end{array}$ & $\begin{array}{r}-0.089 \\
(0.094)\end{array}$ \\
\hline $\mathrm{Age}^{2}$ & $\begin{array}{c}0.393^{\star \star} \\
(0.193)\end{array}$ & $\begin{array}{c}-0.407^{\star} \\
(0.199)\end{array}$ & $\begin{array}{l}0.014 \\
(0.095)\end{array}$ \\
\hline $\begin{array}{l}\text { Location } \\
(\text { Urban =1) }\end{array}$ & $\begin{array}{c}-0.067^{\star \star \star} \\
(0.011)\end{array}$ & $\begin{array}{c}0.098^{\star \star \star} \\
(0.012)\end{array}$ & $\begin{array}{c}-0.031^{\star \star *} \\
(0.006)\end{array}$ \\
\hline $\begin{array}{l}\text { Gender } \\
(\text { Female = 1) }\end{array}$ & $\begin{array}{l}0.018 \\
(0.012)\end{array}$ & $\begin{array}{l}0.012 \\
(0.012)\end{array}$ & $\begin{array}{c}-0.0302^{\star \star \star} \\
(0.006)\end{array}$ \\
\hline $\begin{array}{l}\text { Marital status } \\
(\text { Married }=1)\end{array}$ & $\begin{array}{c}-0.076^{\star \star \star} \\
(0.013)\end{array}$ & $\begin{array}{c}0.079^{\star \star \star} \\
(0.014)\end{array}$ & $\begin{array}{c}-0.0037 \\
(0.007)\end{array}$ \\
\hline Household size & $\begin{array}{l}0.01^{\star * *} \\
(0.002)\end{array}$ & $\begin{array}{c}-0.009^{\star \star \star} \\
(0.002)\end{array}$ & $\begin{array}{r}0.00008 \\
(0.0011)\end{array}$ \\
\hline Primary education & $\begin{array}{c}0.074^{\star \star \star} \\
(0.016)\end{array}$ & $\begin{array}{l}0.012 \\
(0.016)\end{array}$ & $\begin{array}{c}-0.087^{\star * *} \\
(0.007)\end{array}$ \\
\hline Secondary education & $\begin{array}{c}0.162^{\star \star \star} \\
(0.018)\end{array}$ & $\begin{array}{c}-0.055^{\star \star \star} \\
(0.019)\end{array}$ & $\begin{array}{c}-0.107^{\star \star *} \\
(0.009)\end{array}$ \\
\hline Tertiary education & $\begin{array}{c}0.247^{\star * \star} \\
(0.024)\end{array}$ & $\begin{array}{c}-0.167^{\star \star \star} \\
(0.025)\end{array}$ & $\begin{array}{c}-0.079^{\star \star \star} \\
(0.012)\end{array}$ \\
\hline $\begin{array}{l}\text { Dwelling type } \\
(\text { Modern = 1) }\end{array}$ & $\begin{array}{c}0.064^{\star \star \star} \\
(0.018)\end{array}$ & $\begin{array}{l}0.018 \\
(0.019)\end{array}$ & $\begin{array}{c}-0.082^{* * *} \\
(0.007)\end{array}$ \\
\hline Rooms & $\begin{array}{c}0.067^{\star \star \star} \\
(0.005)\end{array}$ & $\begin{array}{c}-0.03^{\star \star \star} \\
(0.005)\end{array}$ & $\begin{array}{c}-0.037^{\star \star *} \\
(0.003)\end{array}$ \\
\hline In(income) & $\begin{array}{c}0.006^{\star * \star} \\
(0.001)\end{array}$ & $\begin{array}{c}-0.007^{\star \star \star} \\
(0.001)\end{array}$ & $\begin{array}{c}0.001 \\
(0.0007)\end{array}$ \\
\hline In(kerosene price) & $\begin{array}{c}0.26^{\star \star \star} \\
(0.02)\end{array}$ & $\begin{array}{c}-0.346^{\star \star \star} \\
(0.021)\end{array}$ & $\begin{array}{c}0.086^{\star \star \star} \\
(0.007)\end{array}$ \\
\hline Observations & & 31,602 & \\
\hline Number of cases & & 10,534 & \\
\hline Wald chi2 & & 747.39 & \\
\hline Prob>chi2 & & 0.0000 & \\
\hline Log simulated-likelihood & & $-7,980.02$ & \\
\hline
\end{tabular}

No education is the reference for education dummies, Standard errors in parentheses, ${ }^{\star \star *} p<0.01,{ }^{\star \star} p<0.05,{ }^{\star} p<0.1$. 
correlation exists between the residuals of each alternative. Hence, the suest-based Hausman test and Small-Hsiao test of IIA assumptions are performed, but one test passes while the other fails, which is not a solid evidence that the IIA assumption is not violated. Therefore, MNP and alternative-specific MNP is used to test the robustness of the results. MNP relaxes the IIA assumption by grouping similar subsets, while alternativespecific MNP removes the IIA assumption by estimating the full correlation matrix of the residuals.

The results of MNP and alternative-specific MNP are shown in Tables 5, 6. The sign and coefficient of the three models (MNL, MNP, and alternative-specific MNP) are similar, which suggests that the IIA assumption has not been violated in the MNL. Therefore, the results are robust in different model specifications.

\section{CONCLUSION AND POLICY RECOMMENDATIONS}

The importance of lighting is often shadowed by other energy demands, such as cooking. However, modern lighting services are crucial for improving the socio-economic welfare of underprivileged people in developing countries. It is important to have a good understanding of the driving factors which influence a household's lighting fuel choice to promote the energy transition. Therefore, this study examines the various socioeconomic determinants of the Kenyan household's lighting fuel choice using multinomial probability models.

This study conducts a case study on Kenya, but many other developing countries also face similar challenges from the low electrification rates, and the households tend to rely heavily on fossil fuels. Therefore, the policy insights drawn from the findings would be useful for the Kenyan government as well as other developing countries. The policy implications regarding the key determinants (income, education, and wealth of a household) of the energy ladder hypothesis have been discussed numerous times in previous studies; hence, will not repeated in this paper.

The first policy suggestion is to empower women and enhance their bargaining power in household decision making process. In developing countries, microfinancing is a method widely used to assist individuals in starting small businesses and relieving their credit constraints. A survey shows that once women were able to purchase mobile phones, they had access to more professional opportunities, and their income increased (Quak, 2018). Also, studies have suggested that women's employment has enhanced

\section{REFERENCES}

Alem, Y., Beyene, A. D., Köhlin, G., and Mekonnen, A. (2016). Modeling household cooking fuel choice: a panel multinomial logit approach. Energy Econ. 59, 129-137. doi: 10.1016/j.eneco.2016.06.025

Andadari, R. K., Mulder, P., and Rietveld, P. (2014). Energy poverty reduction by fuel switching. Impact evaluation of the LPG conversion program in Indonesia. Energy Policy 66, 436-449. doi: 10.1016/j.enpol.2013.11.021

Baek, Y. J., Jung, T. Y., and Kang, S. J. (2019). Low carbon scenarios and policies for the power sector in Botswana. Climate Policy 19, 219-230. doi: 10.1080/14693062.2018.1490243 their bargaining power at home, and the probability of the household purchasing modern lighting devices have increased (Pachauri and Rao, 2013). Therefore, educating and opening opportunities for women would have a positive influence on the household energy transition.

Second, the government should make substantial public investments in constructing community-level solar power plants. The result has shown that urban households have better access to kerosene at a lower price than rural households. This is an opportunity for rural households to leapfrog from traditional lighting fuel to modern lighting fuel. Instead of subsidizing kerosene, it would be more beneficial in the long term if the government could construct community-level solar power plants and subsidize the electricity tariffs.

These are the four reasons for suggesting community-level solar power plants over household solar panels. First, solar panels need to be subsidized by the government for most of the rural households even to attempt a purchase of the system, which in total, would be more expensive than constructing utility power plants. Second, solar panels requires constant maintenance, but it is likely that technicians will not live in small villages, and the household would continue to use fossil fuels as a safety net. On the other hand, if independent power producers (IPP) are contracted, these companies will manage and maintain a stable supply of electricity to make a profit. Third, the cost of renewable energy technologies is constantly declining, which would greatly reduce the investment cost soon (Baek et al., 2019). Lastly, as the population density is increasing, it would be more effective to deal with the rising demand at a community-level (Quak, 2018). Therefore, substantial government funding and political support are crucial for successful rural electrification and household energy transition.

\section{DATA AVAILABILITY STATEMENT}

Publicly available datasets were analyzed in this study. This data can be found here: https://www.knbs.or.ke/.

\section{AUTHOR CONTRIBUTIONS}

YB was responsible for data curation, investigation, analysis, original draft, review, and editing. TJ was responsible for conceptualization, methodology, review, and editing. SK was responsible for analysis, review, and editing. 
Farsi, M., Filippini, M., and Pachauri, S. (2007). Fuel choices in urban Indian households. Environ. Dev. Econ. 12, 757-774. doi: 10.1017/S1355770X07003932

Giri, M., and Goswami, B. (2017). Determinants of households' choice of energy for lighting in Nepal. Econ. Business Lett. 6, 42-47. doi: 10.17811/ebl.6.2.2017.42-47

Harper, M., Alstone, P., and Jacobson, A. (2013). A Growing and Evolving Market for Off-grid Lighting. Available online at: https://www.lightingglobal. org/resource/a-growing-and-evolving-market-for-off-grid-lighting-marketpresence-of-off-grid-lighting-products-in-the-kenyan-towns-of-kerichokapkugerwet-brooke-and-talek/ (accessed April 11, 2019).

Heltberg, R. (2004). Fuel switching: evidence from eight developing countries. Energy Econ. 26, 869-887. doi: 10.1016/j.eneco.2004.04.018

Heltberg, R. (2005). Factors determining household fuel choice in Guatemala. Environ. Dev. Econ. 10, 337-361. doi: 10.1017/S1355770X040 01858

Hiemstra-Van der Horst, G., and Hovorka, A. J. (2008). Reassessing the "energy ladder": household energy use in Maun, Botswana. Energy Policy 36, 3333-3344. doi: 10.1016/j.enpol.2008.05.006

Lam, N. L., Smith, K. R., Gauthier, A., and Bates, M. N. (2012). Kerosene: a review of household uses and their hazards in low-and middleincome countries. J. Toxicol. Environ. Health B Crit. Rev. 15, 396-432. doi: 10.1080/10937404.2012.710134

Lay, J., Ondraczek, J., and Stoever, J. (2013). Renewables in the energy transition: evidence on solar home systems and lighting fuel choice in Kenya. Energy Econ. 40, 350-359. doi: 10.1016/j.eneco.2013.07.024

Leach, G. (1992). The energy transition. Energy Policy 20, 116-123. doi: 10.1016/0301-4215(92)90105-B

Martey, E. (2019). Tenancy and energy choice for lighting and cooking: evidence from Ghana. Energy Econ. 80, 570-581. doi: 10.1016/j.eneco.2019.02.008

Masera, O. R., Saatkamp, B. D., and Kammen, D. M. (2000). From linear fuel switching to multiple cooking strategies: a critique and alternative to the energy ladder model. World Dev. 28, 2083-2103. doi: 10.1016/S0305-750X(00)00076-0

Mekonnen, A., and Köhlin, G. (2009). Determinants of Household Fuel Choice in Major Cities in Ethiopia. Available online at: http://efdinitiative.org/sites/ default/files/publications/efd-dp-13-12.pdf (accessed April 20, 2019).

Ngeno, G., Otieno, N., Troncoso, K., and Edwards, R. (2018). Opportunities for Transition to Clean Household Energy in Kenya: Application of the Household
Energy Assessment Rapid Tool (HEART). Available online at: https://apps.who. int/iris/handle/10665/311281 (accessed May 10, 2019).

Olang, T. A., Esteban, M., and Gasparatos, A. (2018). Lighting and cooking fuel choices of households in Kisumu City, Kenya: a multidimensional energy poverty perspective. Energy Sustain. Dev. 42, 1-13. doi: 10.1016/j.esd.2017.09.006

Pachauri, S., and Rao, N. D. (2013). Gender impacts and determinants of energy poverty: are we asking the right questions?. Curr. Opin. Environ. Sustain. 5, 205-215. doi: 10.1016/j.cosust.2013.04.006

Quak, E. J. (2018). Lighting and Electricity Services for Off-Grid Populations in Sub-Sahara Africa. Available online at: https://assets.publishing.service.gov. uk/media/5af96657ed915d0df4e8cdea/Costs_Benefits_Off-Grid_Electricity_ Lighting_Systems.pdf (accessed May 10, 2019).

Rahut, D. B., Behera, B., Ali, A., and Marenya, P. (2017). A ladder within a ladder: understanding the factors influencing a household's domestic use of electricity in four African countries. Energy Econ. 66, 167-181. doi: 10.1016/j.eneco.2017.05.020

Ruiz-Mercado, I., and Masera, O. (2015). Patterns of stove use in the context of fuel-device stacking: rationale and implications. EcoHealth 12, 42-56. doi: 10.1007/s10393-015-1009-4

Tracy, J., and Jacobson, A. (2012). The True Cost of Kerosene in Rural Africa. Available online at: https://www.lightingafrica.org/publication/truecost-kerosene-rural-africa/ (accessed April 24, 2019).

van der Kroon, B., Brouwer, R., and van Beukering, P. J. (2013). The energy ladder: theoretical myth or empirical truth? Results from a meta-analysis. Renew. Sustain. Energy Rev. 20, 504-513. doi: 10.1016/j.rser.2012.11.045

Conflict of Interest: The authors declare that the research was conducted in the absence of any commercial or financial relationships that could be construed as a potential conflict of interest.

Copyright (c) 2020 Baek, Jung and Kang. This is an open-access article distributed under the terms of the Creative Commons Attribution License (CC BY). The use, distribution or reproduction in other forums is permitted, provided the original author(s) and the copyright owner(s) are credited and that the original publication in this journal is cited, in accordance with accepted academic practice. No use, distribution or reproduction is permitted which does not comply with these terms. 


\section{APPENDIX}

TABLE A1 | Correlation matrix of independent variables.

\begin{tabular}{|c|c|c|c|c|c|c|c|c|c|c|c|c|c|}
\hline & Age & $\mathrm{Age}^{2}$ & Location & Gender & $\begin{array}{l}\text { Marital } \\
\text { status }\end{array}$ & HH size & $\begin{array}{l}\text { Primary } \\
\text { education }\end{array}$ & $\begin{array}{l}\text { Secondary } \\
\text { education }\end{array}$ & $\begin{array}{l}\text { Tertiary } \\
\text { education }\end{array}$ & $\begin{array}{l}\text { Dwelling } \\
\text { type }\end{array}$ & Rooms & Income & $\begin{array}{l}\text { Kerosene } \\
\text { price }\end{array}$ \\
\hline Age & 1 & & & & & & & & & & & & \\
\hline Location & -0.1995 & -0.1918 & 1 & & & & & & & & & & \\
\hline Gender & 0.101 & 0.1056 & -0.0466 & 1 & & & & & & & & & \\
\hline Marital status & 0.0752 & 0.1044 & 0.0537 & 0.4772 & 1 & & & & & & & & \\
\hline $\begin{array}{l}\text { Primary } \\
\text { education }\end{array}$ & -0.0072 & -0.0143 & -0.1294 & -0.0103 & -0.005 & 0.0653 & 1 & & & & & & \\
\hline $\begin{array}{l}\text { Secondary } \\
\text { education }\end{array}$ & -0.157 & -0.1604 & 0.134 & -0.085 & -0.0525 & -0.078 & -0.5504 & 1 & & & & & \\
\hline $\begin{array}{l}\text { Tertiary } \\
\text { education }\end{array}$ & -0.1013 & -0.1043 & 0.1706 & -0.0581 & -0.0401 & -0.0827 & -0.3604 & -0.2303 & 1 & & & & \\
\hline $\begin{array}{l}\text { Kerosene } \\
\text { price }\end{array}$ & -0.0145 & -0.0181 & -0.0493 & -0.0311 & -0.0621 & 0.1364 & -0.0866 & -0.0725 & 0.0019 & -0.2145 & -0.101 & -0.0294 & 1 \\
\hline
\end{tabular}

